\title{
Prevalence of bacterial vaginosis in preterm and term labour: a one year study
}

\author{
Chembetei Kavitha Kiran $^{1 *}$, Jithendra Kandati ${ }^{2}$, Munilakshmi Ponugoti ${ }^{2}$
}

\begin{abstract}
${ }^{1}$ Department of Obstetrics and Gynecology, ${ }^{2}$ Department of Microbiology, Narayana Medical College, Nellore, Andhra Pradesh, India
\end{abstract}

Received: 01 May 2017

Accepted: 04 May 2017

\author{
*Correspondence: \\ Dr. Chembetei Kavitha Kiran, \\ E-mail: sujatha2481@gmail.com
}

Copyright: (C) the author(s), publisher and licensee Medip Academy. This is an open-access article distributed under the terms of the Creative Commons Attribution Non-Commercial License, which permits unrestricted non-commercial use, distribution, and reproduction in any medium, provided the original work is properly cited.

\begin{abstract}
Background: Presence of intra uterine infections is one of the important risk factors for preterm labour. Bacterial vaginosis is one of the commonest genital infections during pregnancy and the prevalence ranges from 4 to $64 \%$ depending upon the racial, geographic factors. Most of the cases of bacterial vaginosis during pregnancy are asymptomatic and goes unrecognized. Some of the studies state that treatment of bacterial vaginosis is not associated with reduction in preterm birth rates among mothers with no history of preterm birth. The present was conducted to study the prevalence of bacterial vaginosis in women presenting with preterm labour and term labour and to analyze the causal relationship between bacterial vaginosis and preterm labour. The study also recorded the outcome of maternal and neonatal complications associated with bacterial vaginosis

Methods: An observational study was conducted on 100 patients with preterm and term labour. Swabs were collected from all the patients and bacterial vaginosis was diagnosed based on Amsel's criteria. Pearson's chi-square test was used to demonstrate the difference between both groups with respect to various categorical data. Independent $t$ - test was used to compare the mean maternal age and mean gestational age at admission in both the groups.

Results: The mean maternal age of members in preterm labour was $25.60+4.295$ and of term labour was $25.38 \pm 4.01$ years. Among preterm labour group only 14 cases were suggestive of bacterial vaginosis and 2 cases among 25 cases in labour group. The proportion of cases who were diagnosed as BV positive based on Amsel's criteria were found more in preterm labour group than term labour group and was found statistically significant $(\mathrm{p}$ value $=0.001$ ). Significantly more number of patients in preterm labour group demonstrated culture swab positivity with pathogenic organisms than in term labour group and was found statistically significant with $\mathrm{p}$ value $=0.048$.

Conclusions: The present study clearly demonstrates significant association of preterm labour with bacterial vaginosis. Therefore, the screening for bacterial vaginosis as a routine during pregnancy and its prompt treatment may reduce the risk of preterm labour. This will also go a long way in the prevention of neonatal complications due to prematurity.
\end{abstract}

Keywords: Amsels's criteria, Bacterial vaginosis, Preterm labour, Term labour

\section{INTRODUCTION}

Among the multiple causes of perinatal mortality and morbidity, in industrial countries the greatest cause is preterm labour. The complications of preterm birth cause approximately $70 \%$ of neonatal deaths and half of all neurological morbidity. ${ }^{1}$ Presence of intra uterine infections is one of the important risk factors for preterm labour. Most of the studies on detection of causes of preterm birth and labour focused on microbial infections of the amniotic cavity and found the common route of infection is ascending route. ${ }^{2}$ Bacterial vaginosis is one of the commonest genital infections during pregnancy and the prevalence ranges from 4 to $64 \%$ depending upon the 
racial, geographic factors. ${ }^{3}$ The pathogenesis of Bacterial vaginosis during pregnancy is associated with many complications like chorioamnionitis, preterm birth and low birth weight among neonates. ${ }^{4}$ The greatest risk of preterm birth is observed if Bacterial vaginosis is present before 16 weeks of gestation. Bacterial vaginosis is the common cause of vaginal discharge during reproductive age. The pathogenesis of bacterial vaginosis is explained by replacement of normal vaginal flora by anaerobic bacteria like Gardenella, Peptostreptococcus, Bacteroides. The products of these bacilli stimulate the deciduas and cause preterm labor..$^{5}$ Most of the cases of Bacterial vaginosis during pregnancy are Asymptomatic and goes unrecognized. Some of the studies state that treatment of Bacterial vaginosis is not associated with reduction in preterm birth rates among mothers with no history of preterm birth.

The present was conducted to study the prevalence of bacterial vaginosis in women presenting with preterm labour and term labour and to analyze the causal relationship between bacterial vaginosis and preterm labour. The study also recorded the outcome of maternal and neonatal complications associated with bacterial vaginosis

\section{METHODS}

The present study was conducted by Department of Obstetrics at Narayana general Hospital which is a tertiary care referral hospital at Nellore, Andhra Pradesh. The study period was for one year from March 2014 to February 2015. To get statistically significant results with $5 \%$ alpha error and $80 \%$ power of the study, a total of 100 subjects were enrolled with $95 \%$ confidence interval. The study was approved by the institutional ethical committee. Pregnant women with preterm and term labour admitted in the obstetrics ward were the main study subjects and informed consent was obtained from all the cases enrolled in the study. A case record form consisting of demographic data, clinical history, gestational age at delivery, and newborn birth weight and conditions was noted. The gestational age was calculated from the first day of the last menstrual period and earliest available ultrasound scan.

\section{Inclusion criteria}

Preterm labour (Group I) was defined as follows:

- Gestational age less than 37 weeks.

- Regular uterine contractions (four or more in 20 minutes or eight or more in 60 minutes), each lasting more than 40 seconds.

- Cervical dilatation equal to or greater than $1 \mathrm{~cm}$ but less than $4 \mathrm{~cm}$ and effacement equal to or greater than $80 \%$.

- Intact fetal membranes.
- Gestational age >37 completed weeks

- Spontaneous in onset.

- Regular uterine contractions (four or more in 20 minutes or eight or more in 60 minutes), each lasting for more than 40 seconds

- Cervical dilatation equal to or greater than $1 \mathrm{~cm}$ but less than $4 \mathrm{~cm}$

- Intact fetal membranes.

\section{Exclusion criteria}

Cases with Rh- isoimmunization, use of antibiotics in the preceding two weeks, multiple gestations, Structural uterine abnormalities, Prior use of tocolytic agents during the current pregnancy, Pregnancies complicated with medical disorders like hypertension, diabetes, chronic renal disorders, thyroid disorders, gastrointestinal disorders, severe cardiac disorders etc. and Current use of corticosteroids.

\section{Specimen collection and processing}

Vaginal discharge was collected with an ayre spatula from the posterior culdesac and spread on two slides. One smear was air dried and gram stained, other was fixed in alcohol and performed Pap smear and examined for clue cells. Whiff test was performed by adding $\mathrm{KOH}$ on the slide to detect amine odor. The $\mathrm{pH}$ of vaginal discharge was tested using litmus paper.

Bacterial vaginosis was diagnosed if 3 or more of the following criteria were present (Amsel's criteria):

- $\quad$ elevated vaginal $\mathrm{pH}>4.5$;

- thin, homogeneous gray-white discharge;

- amine odor upon the addition of $10 \%$ potassium hydroxide $(\mathrm{KOH})$ to vaginal fluid on a glass slide (whiff test);

- $\quad$ presence of 'clue cells' (vaginal epithelial cells with indistinct borders due to attached bacteria) on microscopic examination of vaginal fluid.

A score of 0 was assigned to the most lactobacilluspredominant vaginal flora, and a score of 10 was assigned to a flora in which Lactobacilli were largely replaced by Gardnerella, Bacteroides, and Mobiluncus (Nugent's scoring). ${ }^{6}$ Women fulfilling the Amsel's criteria and/or a score of 7 or more on Gram's staining of the vaginal smear (Nugent's score) were considered to have bacterial vaginosis.

Vaginal swab was sent for culture for isolation of bacterial and fungal pathogens. The swab was inoculated on sheep Blood agar and Sabourad's dextrose agar and examined for growth. Group B streptococcus was identified by colony morphology and biochemical characters. Candida spp. were identified by gram's staining and germ tube test. Blood was collected from the

Term labour (Group II) was defined as follows: 
neonates of Bacterial vaginosis positive cases and estimation of CRP was done and values noted.

\section{Statistical analysis}

All the data was entered in excel spread sheet for preparation of tables and charts. SPSS version 17 was used to calculate statistical data. Categorical variables were represented as frequency and percentages and Pearson's Chi-square test was used to find out the significance of differences in the various categorical data in both the groups.

\section{RESULTS}

In the present study conducted at Obstetrics ward of Narayana general hospital, total of 100 cases were studied who fulfilled the inclusion criteria. Out of 100 cases, 50 were in preterm labour and other 50 in term labour. Both were considered as Group I and Group II.

Table 1: Attributes of vaginal discharge.

\begin{tabular}{|l|l|l|}
\hline $\begin{array}{l}\text { Type of } \\
\text { discharge }\end{array}$ & $\begin{array}{l}\text { Preterm } \\
\text { labour } \\
(\mathrm{N}=50) \mathrm{n}(\%)\end{array}$ & $\begin{array}{l}\text { Term labour } \\
(\mathrm{N}=50) \mathrm{n}(\%)\end{array}$ \\
\hline $\begin{array}{l}\text { No discharge } \\
\begin{array}{l}\text { White mucoid } \\
\text { discharge }\end{array}\end{array}$ & $12(28.0)$ & $25(50)$ \\
\hline $\begin{array}{l}\text { White curdy } \\
\text { discharge }\end{array}$ & $10(20.0)$ & $4(8.0)$ \\
\hline $\begin{array}{l}\text { Greyish white } \\
\text { discharge }\end{array}$ & $8(16.0)$ & $2(4.0)$ \\
\hline $\begin{array}{l}\text { Grey frothy } \\
\text { discharge }\end{array}$ & $4(8.0)$ & $0(0.0)$ \\
\hline $\begin{array}{l}\text { Greenish frothy } \\
\text { discharge }\end{array}$ & $2(4.0)$ & $0(0.0)$ \\
\hline $\begin{array}{l}\text { Vaginal pH (Basic) } \\
\text { Whiff test (+ve) }\end{array}$ & $22(44.0)$ & $7(14.0)$ \\
\hline $\begin{array}{l}\text { BV by Amsel's } \\
\text { Criteria }(\geq 3)\end{array}$ & $15(30.0)$ & $2(4.0)$ \\
\hline Total (N=100) & $50(100.0)$ & $50(100.0)$ \\
\hline
\end{tabular}

In both the groups there was no significant major difference in age. The mean maternal age of members in preterm labour was $25.60+4.295$ and of term labour was $25.38 \pm 4.01$ years. The mean maternal age was comparable in both the groups with $p$ value of 0.792 . The number of primigravidas and multigravidas were equal in both the groups ( 25 in each group). The mean gestational age (period of gestation) at the time of admission in group I (pre-term labour) was 33.5 weeks and in group II (term labour) was 39 weeks, and statistical significance was associated with period of gestation among both groups ( $\mathrm{p}$ value $<0.0001)$. 6 cases $(12 \%)$ in group I and 1 in group II $(2 \%)$ had old history of sexually transmitted infection and this proportion of cases were significant with $\mathrm{p}$ valve $=0.050$.
Out of 50 cases in group I, 36 had vaginal discharge (72\%) and only 25 cases $(50 \%)$ in group II. The proportion of cases with discharge were more in preterm labour group than term labour group and was found to be statistically significant ( $\mathrm{p}$ value of 0.005 ). The nature of the discharge was also noted and characterized as bacterial vaginosis (Table 1). Out of 36 cases with vaginal discharge among preterm labour group only 14 cases were suggestive of bacterial vaginosis and 2 cases among 25 cases in labour group. The proportion of cases suggestive of BV were more in preterm labour group than term labour and was found statistically significant with $\mathrm{p}$ value of 0.001 . 22 cases (44\%) among preterm labour and 7 cases (14\%) among term labour were found with vaginal discharge having basic $\mathrm{pH}$. This association of basic vaginal $\mathrm{pH}$ was found to be significant with $\mathrm{p}$ value $=0.001$.

Whiff test positivity was observed in 22 cases (44\%) of group I and 9 cases (18\%) of group II, and this difference noted among two groups was found statistically significant ( $\mathrm{p}$ value <0.005) Considering the Amsel's criteria with $\geq 3$ as positive, 15 cases $(30 \%)$ in group I and 2 cases (4\%) in group II were diagnosed as bacterial vaginosis. The proportion of cases who were diagnosed as BV positive based on Amsel's criteria were found more in preterm labour group than term labour group and was found statistically significant ( $\mathrm{p}$ value $=0.001$ )

Table 2: Results of high vaginal swab culture in both the groups.

\begin{tabular}{|c|c|c|c|}
\hline HVS C/S & $\begin{array}{l}\text { Preterm } \\
\text { labour } \\
(\mathbf{N}=50) \\
\text { n }(\%)\end{array}$ & $\begin{array}{l}\text { term } \\
\text { labour } \\
(\mathrm{N}=\mathbf{5 0}) \\
\mathrm{n}(\%)\end{array}$ & $\begin{array}{l}\text { Total } \\
(\mathrm{N}=100) \\
\mathrm{n}(\%)\end{array}$ \\
\hline Normal flora & $39(78.0)$ & $47(94.0)$ & $86(86.0)$ \\
\hline Candida & $4(8.0)$ & $3(6.0)$ & $7(7.0)$ \\
\hline $\begin{array}{l}\text { Group B } \\
\text { Streptococcus }\end{array}$ & $1(2.0)$ & $0(0.0)$ & $1(1.0)$ \\
\hline Enterococcus & $6(12.0)$ & $0(0.0)$ & $6(6.0)$ \\
\hline $\begin{array}{l}\text { Total }(\mathrm{N}=100) \\
\mathrm{n}(\%)\end{array}$ & $50(100)$ & $50(100)$ & $100(100)$ \\
\hline
\end{tabular}

Results of high vaginal swab cultures in preterm labour cases revealed, 39 cases (78\%) with normal flora and 11 cases (22\%) with pathogenic microorganisms. Enterococcus was isolated in 6 of 11 cases and 4 cases of candida and 1 case of Group B streptococcus. In cases of term labour, 47 cases $(94 \%)$ had normal flora and only 3 cases $(6 \%)$ demonstrated candida as the isolate. Significantly more number of patients in preterm labour group demonstrated culture swab positivity with pathogenic organisms than in term labour group and was found statistically significant with $\mathrm{p}$ value $=0.048$ (Table2). The mean CRP value recorded in preterm labour group was $1.2 \pm 1.0$ and was significantly more in preterm labour group than in term labour group $(0.75 \pm 0.5)$, and the difference was statistically highly significant (p value $=0.002$ ). 
8 neonates $(53.3 \%)$ born to 15 positive cases of BV had low birth weight (LBW), compared to 29 neonates $(82.8 \%)$ of LBW born to 35 negative cases of BV and the difference was not statistically significant. ( $p$ value $=0.230$ ). In term group $50 \%$ of neonates born to BV positive mothers had low birth weight as compared to $18 \%$ of neonates born to BV negative mothers. This difference was not significant statistically ( $p=0.180$ ). Statistically significant association was also not observed in newborn that developed complications when compared to bacterial vaginosis negative cases ( $p$ value $=0.333$ ). In term labour group no neonates of BV positive mothers had neonatal complications, while $4.1 \%$ of neonates of $\mathrm{BV}$ negative mothers had neonatal complications. The difference was not significant statistically. In preterm labour group $26.6 \%$ of patients who were BV positive had postpartum complications and none in term labour group and the association was also not statistically significant. The most common complication was puerperal pyrexia followed by atonic PPH (Table 3).

Table 3: Maternal and foetal outcome chart in BV +ve cases.

\begin{tabular}{|lll|}
\hline Outcome & $\begin{array}{l}\text { Bacterial } \\
\text { vaginosis }(+\mathrm{ve}) \\
\text { in PTL }(\mathbf{n}=\mathbf{1 5})\end{array}$ & $\begin{array}{l}\text { Bacterial } \\
\text { vaginosis } \\
(+\mathrm{ve}) \text { in } \\
\text { TL }(\mathrm{n}=\mathbf{2})\end{array}$ \\
\hline Low birth weight & 8 & 1 \\
\hline Normal birth weight & 7 & 1 \\
\hline $\begin{array}{l}\text { Presence of neonatal } \\
\text { complications }\end{array}$ & 3 & 0 \\
\hline Development of PPH & 4 & 0 \\
\hline
\end{tabular}

\section{DISCUSSION}

The causal relationship between vaginal microflora and spontaneous preterm birth has gained lot of importance, and the underlying pathogenic mechanisms are not clearly understood. The role of specific vaginal microorganisms as risk factor for spontaneous preterm birth varies according to the study conducted, the geographic location and ethnic race of the study group. ${ }^{7}$ Bacterial vaginosis is one of the common reproductive tract infections associated with vaginal discharge (prevalence 10-15\%), and is found in $20 \%$ of pregnant women. Most of these cases during pregnancy are asymptomatic and goes unnoticed unless screened. ${ }^{8}$ Few studies have reported association of $\mathrm{BV}$ with low socioeconomic status and lack of proper vaginal hygiene practices e. g: using clothes during menstruation etc. ${ }^{9}$

The mean gestational age of both preterm labour group and term labour group, maternal age of study group and gravidity were similar to findings of Chawanpaiboon $\mathrm{S}$ et al who reported almost similar findings in relation to parity and period of gestation. ${ }^{10}$ In the present study Trichomoniasis was the commonest STI associated with preterm labour group and findings of Leitch $\mathrm{H}$ et al confirms with findings in our study. ${ }^{11}$ However, findings in the study of Azargoon A et al were contrary to findings in present study and exhibited no significant association between trichomoniasis and preterm labor. ${ }^{12}$ In present study, 36 cases $(72 \%)$ cases had vaginal discharge in preterm group and 25 cases $(50 \%)$ in term group, which coincides with the findings of Nwosu et al who reported $40 \%$ of cases in preterm and $28 \%$ in term group. ${ }^{13}$

Findings in the study of Paulo. CG et al have proved that lower genital tract infections are very common among apparently healthy looking pregnant women with an overall prevalence of $40-54 \% .{ }^{14}$ The prevalence of BV during pregnancy has been reported as $20-30 \%$ in various studies. The present study estimated the prevalence of BV based on positive Amsel's criteria among preterm labour group as $30 \%$ and among term labour as $4 \%$ which coincides with the findings of Mittal et al and Svare et al. ${ }^{15,16}$ Findings in the study of Hiller and coworkers and Subtil et al demonstrated the increased association of preterm delivery with bacterial vaginosis which is also demonstrated in the present study. ${ }^{17,18}$ In the present study significant other infections were more common in preterm labour group than term group and most common infection was candida among term labour group and Enterococus in Preterm labour group.

In the present study $3 \%$ of the patients were positive for Group B Streptococci. (2\% in preterm group and $1 \%$ in term group). This finding is contrary to findings of Benchetrit et al who reported the prevalence of GBS as $26 \%$ among pregnant women in his study. ${ }^{19}$ Incidence of neonatal complications was higher among infants born to preterm labour group than among term labour group. Findings of Hay AE et al confirms with our findings but some studies have reported other factors in association with BV as a cause of increases neonatal complications. ${ }^{20}$ In term labour group none of the neonates of $\mathrm{BV}$ positive mothers had neonatal complications, while $4.1 \%$ of neonates of BV negative mothers had respiratory distress. This observation probably indicated that BV had no role in the causation of neonatal complications in case of term labour in this study. Puerperal pyrexia was the commonest post-partum complication seen in preterm labour group in both BV positive and negative mothers. Postpartum complications were not observed in term labour group in $\mathrm{BV}$ positive cases while $12.5 \%$ of $\mathrm{BV}$ negative cases reported postpartum complications.

\section{CONCLUSION}

To conclude the present study clearly demonstrates significant association of preterm labour with bacterial vaginosis. Therefore, the screening for bacterial vaginosis as a routine during pregnancy and its prompt treatment may reduce the risk of preterm labour. This will also go a long way in the prevention of neonatal complications due to prematurity.

\section{Funding: No funding sources \\ Conflict of interest: None declared}


Ethical approval: The study was approved by the Institutional Ethics Committee

\section{REFERENCES}

1. McCormick MC. The contribution of low birth weight to infant mortality and childhood morbidity. N Engl J Med. 1985;312:82-90.

2. Romero R, Mazor M. Infection and preterm labor. Clin Obstet Gynecol. 1988;31:553-84.

3. Guaschino S, De Seta F, Piccoli M, Maso G, Alberico S. Aetiology of preterm labour: bacterial vaginosis. BJOG. 2006;113(Suppl 3):46-51

4. Donders GG, Van Bulck B, Caudron J, Londers L, Vereecken A, Spitz B. Relationship of bacterial vaginosis and mycoplasmas to the risk of spontaneous abortion. Am J Obstet Gynecol. 2000;183:431-7.

5. Lamont RF, Anthony F, Myatt L, Booth L, Furr PM, Taylor-Robinson D. Production of prostaglandin E2 by human amnion in vitro in response to addition of media conditioned by microorganisms associated with chorioamnionitis and preterm labor. Am J Obstet Gynecol. 1990;162:819-25.

6. American College of Obstetricians and Gynecologists. Assessment of risk factors for preterm birth. Clinical management guidelines for obstetrician-gynecologists. ACOG Practice Bulletin. J Obstet Gynecol. 2001;98(4):709-16.

7. Priestley CJ, Jones BM, Dhar J, Goodwin L. What is normal vaginal flora? Genitourin Med. 1997;73:23-8.

8. Hillier SL. Diagnostic microbiology of bacterial vaginosis. Am J Obstet Gynecol. 1993;169:455-9.

9. Newton ER, Piper J, Peairs W. Bacterial vaginosis and intraamniotic infection. Am J Obstet Gynecol. 1997; 176:672-7.

10. Chawanpaiboon S, Pimol K. Bacterial vaginosis in threatened preterm, preterm and term labour. J Med Assoc Thai. 2010;93(12):1351-5.

11. Leitich H, Bodner-Adler B, Brunbauer M, Kaider A, Egarter C, Husslein P. Bacterial vaginosis as a risk factor for preterm delivery: a meta-analysis. Am J Obstet Gynecol. 2003;189:139-47.

12. Azargoon A, Darvishzadeh S. Association of bacterial vaginosis, Trichomonas vaginalis, and vaginal acidity with outcome of pregnancy. Arch Iran Med. 2006;9(3):213-7.

13. Nwosu CO, Djieyep NA. Candidiasis and trichomoniasis among pregnant women in a rural community in the semiarid zone, north-eastern Nigeria. West Afr J Med. 2007;26(1):17-9.

14. Giraldo PC, Aráujo ED, Junior J, Amaral RLG, Passos MRL, Gonsalves AK. The prevalence of urogenital infections in pregnant women experiencing preterm and full-term labor. Infect Dis Obstet Gynecol. 2012;2012.

15. Sangita, Mittal A, Chandra P, Gill AK. Incidence of Gardnerella vaginalis in preterm labour. Obstet Gynecol Today. 1999;4(5):299-303.

16. Svare JA, Schmidt H, Hansen BB, Lose G. Bacterial vaginosis in a cohort of Danish pregnant women: prevalence and relationship with preterm delivery, low birthweight and perinatal infections. BJOG. 2006;113(12):1419-25.

17. Hillier SL, Nugent RP, Eschenbach DA, Krohn MA, Gibbs RS, Martin DH et al. Association between bacterial vaginosis and preterm delivery of a lowbirth-weight infant. The Vaginal Infections and Prematurity Study Group. N Engl J Med. 1995;333(26): 1737-42.

18. Subtil D, Denoit V, Le Gouëff F, Husson MO, Trivier D, Puech F. The role of bacterial vaginosis in preterm labor and preterm birth: a case-control study. Eur J Obstet Gynecol Reprod Biol. 2002;101(1):416.

19. Benchetrit LC, Francalanza SE, Peregrino H, Camelo AA, Sanches LA. Carriage of Streptococcus agalactiae in women and neonates and distribution of serological types: a study in Brazil. J Clini Microbiol. 1982;15(5):787-90.

20. Hay PE, Morgan DJ, Ison CA, Bhide SA, Romney $\mathrm{M}$, McKenzie $\mathrm{P}$ et al. A longitudinal study of bacterial vaginosis during pregnancy. $\mathrm{Br} \mathrm{J}$ Obstet Gynaecol. 1994;101(12):1048-53.

Cite this article as: Kiran CK, Kandati J, Ponugoti M. Prevalence of bacterial vaginosis in preterm and term labour: a one year study. Int J Reprod Contracept Obstet Gynecol 2017;6:2292-6. 